\title{
Certainty of Jurisdiction Law in Civil Law System
}

DOI: https://doi.org/10.47175/rissj.v1i2.52

\author{
1,2Lecturer of Law Faculty of \\ Universitas Muhammadiyah \\ Sumatera Utara, Indonesia \\ ${ }^{1}$ rachmadabduh@umsu.ac.id \\ 2idahanifah@umsu.ac.id
}

| Rachmad Abduh ${ }^{1}$ | Ida Hanifah ${ }^{2}$ |

\begin{abstract}
When a law is incomplete or unclear to decide a case, that's when the judge must search and find the law (rechtsviding). The discovery of this law can be done by exploring the legal values that develop in society. There are two methods in legal discovery, first by using the method of interpretation or interpretation, the second using the method of legal construction which finally the decision is known as Jurisprudence. Countries that adhere to the civil law system, especially Indonesia, make jurisprudence as a source of formal law, while, as is known, civil law countries are very dependent on norms or laws and regulations. If the principle of justice prevailing in Indonesian judges is not bound by previous judges' decisions regarding similar cases, then lately not a few judges have dropped their decisions, oriented towards higher court decisions regarding similar cases. This does not mean that the principle is changed to "the bnindingforce of precedent", as embraced by Anglo saxon countries but "bound" or the judge's orientation to the previous ruling because "the persuasive force of precedent" was caused by the ruling that was followed, " binding it "convinced the judge to be followed.

KEYWORDS

Jurisprudence; Legal Systems; Legal Certainty
\end{abstract}

\section{INTRODUCTION}

Settlement of a case in court there are 3 elements that are the focus of public attention, namely the judge examining and deciding the case, the law imposed in the settlement of the case, and the parties/actors in the case. Judges are the main apparatus in a judicial institution. It is in the hands of the Judge that a person's destiny is determined, so that the judge becomes the final foundation for the community seeking justice and truth. Knowledge of law from various communities from various aspects for a judge greatly influences the style of concrete law that will be imposed. (Kamil \& Fauzan, 2005). In deciding a case, the Judge adheres to a rule governing how to decide the case that is being examined. But sometimes legal regulations are incomplete while legal events have occurred.

The legal system in the world consists of several legal systems, namely: the European Continental (Civil Law), the Anglo-saxon (Common Law) legal system, the religious legal system, the socialist legal system and in Indonesia there is customary law. Each legal system has its own characteristics. For example the Continental European legal system, literally a civil law system, developed or embraced in mainland European countries such as Germany, the Netherlands, France, Italy, Latin America, Japan, Thailand and Indonesia. The Continental European Legal System prioritizes written law, namely statutory regulations as the main basis of the legal system, so this legal system is also called the Codified Law system. Codification of the law is a collection of various legal methods that existed before the Justinian period called corpus juris civil. In its development, the legal principles 
contained in Corpus juris ciilis were used as the basis in the formulation and codification of law in mainland Europe (Winata, 2016).

It has been mentioned above that the judge decides a case in the Civil Law system is bound in a regulation governing the legal event, but not all legal events have rules, in the Netherlands known as "het recht hink achter de feiten aan", "the law goes behind event". So the question arises how the judge decided the legal event. Article 22A.B (Algemene Bepalingen) "If a judge refuses to settle a case on the grounds that the relevant law does not mention it, is unclear or incomplete, he can be sued for refusing to prosecute." In line with Law Number 48 of 2009 Concern Judicial authority Article 10 paragraph (1) "The court is prohibited from refusing to examine, try and decide on a case which is filed under the pretext that the law does not exist or is unclear, but it is obligatory to examine and try it."

The provisions of the Article give meaning to the judge as the main organ in a court and as the executor of the judicial power, to receive, examine, try a case and subsequently give a ruling (Kamil \& Fauzan, 2005).

In general, laws are made by legislators to protect human interests, so they must be implemented and enforced. However, it should be remembered that the activities in human life are very broad, not counted in number and type, so it is impossible to be covered in a statutory regulation completely and clearly. Humans as creatures created by God, have limited ability, so the laws they make, are not complete to cover the whole activities of life, therefore there are no laws that are as complete as possible or as clear as possible. (Mertokusomo, 1998).

When a law is incomplete or unclear to decide a case, that's when the judge must search and find the law (rechtsviding). The discovery of this law can be done by exploring the legal values that develop in society. There are two methods in legal discovery, first by using the method of interpretation or interpretation, secondly by using the method of legal construction which is finally known as Jurisprudence.

In the context of studying formal sources of law, it is usually given the understanding that jurisprudence is one source of law in the formal sense. It must be realized that jurisprudence in the civil law family system does not carve the binding force of the precedent as the jurisprudence within the family of the common law system. Nevertheless, from time to time the role of jurisprudence in the development of the legal system in all families of the legal system is felt to be even stronger. (Shidarta, 2012).

\section{RESEARCH METHOD}

This research method uses the normative legal research method. Normative legal research is legal research conducted by examining the library materials consisting of premier legal materials, secondary legal materials and tertiary legal materials. (Soerjono \& Mamudji, 1996)

\section{RESULTS AND DISCUSSION}

\section{Jurisprudence in the Civil Law System in Indonesia}

As one of the formal legal sources of jurisprudence has an important role in the development of law, especially in the common law system. Countries that adhere to the Continental European system have long known and enriched with jurisprudential rulings. Among the various definitions of jurisprudence, one of the definitions commonly understood from the definition of jurisprudence is the understanding used by Soebekti who mentions the definition of jurisprudence as decisions of judges or courts which are fixed and justified by the Supreme Court (MA) as court of cassation, or Supreme Court decisions itself which remains. 1 in other words so far in general the notion of jurisprudence is a 
Supreme Court decision containing legal breakthroughs so that it is constantly followed by courts under the Supreme Court hierarchy, even normatively there are provisions governing that the collection of jurisprudence is the exclusive authority of the Supreme Court.

However, in the latest developments it turns out that the term jurisprudence is also used to refer to the binding decisions of the Constitutional Court (MK) in certain legal issues. For example, recently Oly Viana Agustine stated in her article that jurisprudence was one source of law in judicial review in the Constitutional Court. Jurisprudence applies when the panel of judges believes that previous decisions are still relevant to current constitutional issues. (Simanjuntak E., 2019).

Enrico Simanjuntak. (Hamdi, 2019) is further to emphasize that jurisprudential law (case-law) refers to the creation and improvement of law in formulating court decisions. Because it is oriented towards concrete cases, in which among the series of cases the legal norms are then sought which then become the norm that is applied and followed in various similar cases, the doctrine of precedent or stare decision becomes the heart of the British legal system (or the common law system in general). The doctrine of binding precedent (the doctrinaire of binding precedent), refers to the facts, in the hierarchical structure of Justice in England, higher court decisions bind hierarchically lower courts. In general, this means that when judges hear cases, they will check whether the same matter has been decided by the previous court. If a situation arises or a series of facts as before, then the decision will be given by the court can be expected to be the same as the decision handed down at that time.

In the development of jurisprudence, jurisprudence has an important role, in addition to being a source of legal jurisprudence as well as a guide or reference for judges in deciding the legal events they face and making jurisprudence a product of the judiciary. This is in line with the opinion of Sudikni Mertokusuno, who said that the jurisprudence itself in judges making decisions is to fill the legal vacuum so that they cannot reject a case because there is no law governing it. The legal vacuum can only be overcome and covered through "judge made law" which will serve as a guideline as jurisprudence until the creation of a complete and standard legal codification. (Mertokusomo, 1998).

The main characteristic that forms the basis of the Civil Law system is that the law obtains binding power, because it is manifested in regulations in the form of laws and systematically arranged in the codification. This basic characteristic is held in view that the main value which is the goal of law is legal certainty. Legal certainty can only be realized if human legal actions in the association of life are regulated by written legal regulations. With the purpose of the law and based on the legal system adopted, judges cannot freely create laws that have general binding force. The judge only functions to set and interpret the rules within the limits of his authority. Decisions of a judge in a case only bind the parties to the case alone (Nurhardianto, 2015)

Countries that adhere to the civil law system, especially Indonesia, make jurisprudence as a source of formal law, while as is known, civil law countries are very dependent on norms or laws and regulations. Civil law countries put the constitution at the top of the hierarchy of statutory regulations. The legal system in Indonesia adheres to the Continental European legal system or Civil Law. Because in the form of regulations in the form of laws that are arranged systematically in the codification. The purpose of law is legal certainty. The famous adage "there is no law other than law". Codification is needed to create legal uniformity in and amidst legal diversity. This situation makes jurisprudence play an important role in filling the legal vacuum, when judges must decide legal events. 


\section{Legal Certainty Jurisprudence in the Civil Law Legal System}

Forms of legal sources in the formal sense in the Civil Law system are legislation, customs, and jurisprudence. In order to find justice, jurists and judicial and quasi-judicial institutions refer to these sources. From these sources, the first reference in the tradition of the Civil Law system is legislation. Civil law countries put the constitution at the top of the hierarchy of statutory regulations. All civil law countries have a written constitution. (Lemek, 2007). This is what makes the civil law legal system very fortunate with the laws and regulations which eventually become a problem. In the Anglo-Saxon justice system, jurisprudence is "The binding force of precedent", if in the Continental system it is "Persuasive precedent".

In countries that adhere to the tradition of continental law, generally the term jurisprudence refers to the decision of a high court (usually the highest court) about a matter. Although not formally binding, this decision in practice has a strong influence and is often applied by judges in lower courts later if the facts in the case he hears are similar to the facts in cases where jurisprudence is established. Meanwhile, in the Continental European system (civil law system) adopted by Indonesia, the term jurisprudence is known. Jurisprudence can be classified as 'persuasive precedent'. However, the persuasive nature only applies in the country of Indonesia. This is different from the persuasive precedents found in Anglo-Saxon countries which are still advised to follow precedents in other Commonwealth countries (Salmande, 2011). This resulted in the Supreme Court jurisprudence (MA) not required to be followed by courts under the Supreme Court.

It is not an obligation for courts under the Supreme Court to make jurisprudence a precedent, making law enforcement and justice problems. In the same legal event two different decisions can occur. Sudikno Mertokusumo (Machmudin, 2000) argues that jurisprudence is as a judiciary in general (judicature, rechtspraak), namely the implementation of law in terms of concrete demands for rights carried out by an independent body and held by the state and free from any influence or anyone by way of give binding and authoritative decisions.

In jurisprudence there are two principles that influence whether a judge follows the previous judge or not. The principles consist

\section{The precedent principle}

This principle means that a judge is bound by other judges, both equal and higher. Judges in adjudicating and deciding cases must not deviate from other judges, both equal and higher. The precedent principle is adopted in the United States, United Kingdom, and South Africa. The precedent principle or can also be called a stare dicisie is a judicial institution that is better known in the Anglo-Saxon State or the Common Law System.

2. Free principle

This principle means that a judge is not bound by the decisions of other judges, both equal and higher. Unrestricted words here mean that a judge, in deciding a case may follow the decisions of previous judges, both equal and higher, may also not follow. This free principle is adopted by continental European countries or civil law systems such as the Netherlands, France and Indonesia, (Machmudin, 2000).

Judges' decisions can become a source of formal law if they are followed by the next judge known as jurisprudence. Jurisprudence can be born in connection with the principle in law that judges must not refuse to hear cases submitted to them. Judges as law enforcement and justice are obliged to judge, follow and understand the legal values that live in society, so in handling cases the judge can do.

1. Implement in concreting the existing legal rules (in abstract) and have been valid since before. 
2. Look for yourself the legal rules based on the legal values that live in society. (Marbun \& MD, 2006).

Because judges are not bound by other decisions in terms of regulations that have not been regulated in a legal event make jurisprudence in the civil law legal system may not have a sense of legal certainty. At the same legal event two different decisions can occur. This is contrary to the legal objectives, one of which is certainty. Normative legal certainty is when a statutory regulation is made and promulgated with certainty, because it regulates clearly and logically. Clearly in the sense is not causing the doubts (multiple interpretations), and logical in the sense of being a system of norms with other norms, so that they do not clash or cause norm conflicts. Conflicts of norms arising from the uncertainty of laws and regulations can take the form of norm contestation, norm reduction, or norm distortion. In practice, if legal certainty is associated with legal justice, it will often not be in line with one another. This is because on one hand it is not uncommon for legal certainty to ignore the principles of legal justice. On the other hand it is not uncommon for legal justice to ignore the principles of legal certainty. If in practice there is a conflict between legal certainty and legal justice, then legal justice must take precedence. The reason is, that legal justice in general is born from the conscience of the giver of justice, whereas legal certainty is born of a concrete thing.

According to Gustav Radbruch there are two kinds of definitions of legal certainty, namely legal certainty due to law, and legal certainty in or from law. Successful law guarantees a lot of legal certainty in society is useful law. Legal certainty because the law gives two other legal tasks, namely ensuring legal and legal justice must remain useful; whereas legal certainty in law is achieved, if the law is as much as possible laws. There are no conflicting provisions in the law (the law is based on a logical and practical system). The law is made based on rechtswerkelijkheid (serious legal conditions) and in the law there are no terms that can be interpreted differently (Reza, 2017).

Legal certainty can only be answered normatively rather than sociologically, said to be normative when a rule is made and legalized with certainty that is clear and logically acceptable, does not cause doubt, does not have much understanding and can clash with other norms.

\section{CONCLUSION}

Satjipto, (Rifai, 2011) The essence of the deterioration and setback of the law is that honesty, empathy and dedication in carrying out the law become something that is increasingly rare and expensive. Lots. The legal vacuum that forces the judge to be able to make legal discovery in resolving a legal event will cause problems if the next judge does not follow the previous judge's decision, so that legal certainty in a similar legal event will not be achieved.

In Indonesia, there are heteronomous legal findings as long as judges are bound by the law, but these legal findings also have strong autonomous elements, because judges often have to explain or supplement laws according to their own views. If the principles of justice prevailing are in Indonesia, the judges are not bound by previous judges' decisions regarding similar cases. The lately not a few judges have dropped their decisions, oriented towards higher court decisions regarding similar cases that they are facing. This does not mean that the principle is changed to "the bnindingforce of precedent", as embraced by the Anglo saxon countries but "bound" or the judge's orientation to the previous ruling because "the persuasive force of precedent" was caused by the ruling that was followed, " binding it "convinced the judge to be followed. (Mertokusumo, Legal Discovery An Introduction, 2009) 


\section{REFERENCES}

Buana, D. (2017, 6). Hukum Perdata Materiil Dan Formil. Dipetik 7 22, 2020, dari https://artikelddk.com/hukum-perdata-materiil-dan-hukum-perdata-formil/

Hamdi, M. F. (2019). Kedudukan Yurisprudensi Putusan Mahkamah Konstitusi Dalam Merekonstruksi Hukum Acara. Jurnal Legislasi Indonesia, 16(2), 316.

Kencana, I. (2003). Sistem Adminitrasi Negara Republik Indonesia (SANRI). Jakarta: Bumi Aksara.

Kamil, A., \& Fauzan, M. (2005). Kaidah-Kaidah Hukum Yurisprudensi. Jakarta: Kencana Prenada Media Group.

Lemek, J. (2007). Mencari Keadilan, Pandangan Keritis terhadap Penegakan Hukum Di Indonesia. Jakarta: Galang Pres.

Machmudin, D. D. (2000). Pengantar Ilmu Hukum (sebuah Sketsa),. Bandung: PT. Refika Aditama.

Mertokusumo, S. (2003). Mengenal Hukum (Suatu Pengantar). yogyakarta: liberty.

Marbun, S., \& MD, M. M. (2006). Pokok-Pokok Administrasi Negara. Yogyakarta: Liberty.

Mertokusomo, S. (1998). Hukum Acara Perdata. Yogyakarta: liberty.

Nurhardianto, F. (2015). Sistem Hukum Dan Posisi Hukum Indonesia. Jurnal TAPIs, 2.

Reza, M. (2017, November). Kepastian Hukum. Dipetik Juli 23, 2020, dari https://www.metrokaltara.com/kepastian-hukum/

Rifai, A. (2011). Penemuan Hukum Oleh hakim. Jakarta: Sinar Grafika.

Simanjuntak, E. (2019). Peran Yurisprudensi dalam Sistem Hukum di Indonesia. Jurnal Konstitusi, 16(1), i.

Salmande, A. (2011, September 27). Perbedaan Sifat Mengikat antara Preseden dengan Yurisprudensi. Dipetik juli, 23, 2020, dari https://www. Hukum online.com/klinik/detail/ulasan/cl1679/yurisprudensi/

Shidarta. (2012). Mencari Jarum "Kaidah"di Tumpukan Jerami 'Yurisprudensi'. Jurnal Komisi Yudisial, 5(3), 331.

Simanjuntak, E. (2019). Peran Yurisprudensi dalam Sistem Hukum di Indonesia. Jurnal Konstitusi, 16(1), 1.

Soerjono, S., \& Mamudji, S. (1996). Penelitian Hukum Normatif Suatu Tinjauan Singkat. Jakarta : PT Raja.

Volmar. (1983). Pengantar Studi Hukum Perdata. Jakarta: Ichtiar Baru.

Winata, D. A. (2016). Sistem Hukum Dunia. Dipetik 7 21, 2020, dari https://ekampushukum.blogspot.com/2016/05/sistem-hukum-di-dunia.html 